\title{
Physicochemical changes during 4 weeks ripening of Camembert cheeses salted with four types of salts
}

\author{
Hyung Churl Bae', Joong Hyeon Nam, Gereltuya Renchinkhand ${ }^{1}$, Suk-Ho Choi ${ }^{2}$ and Myoung Soo Nam ${ }^{1 *}$ (i)
}

\begin{abstract}
The objectives of this study were to compare physicochemical, rheological and sensory characteristics of Camembert cheeses salted with 4 types of salts (refined salt, baked refined salt, sun-dried salt, and Himalayan rock salt) during 4 weeks ripening period. The $\mathrm{pH}$ of Camembert cheese was 7.2 in the sun-dried salt, which was the highest than the other three types of salts. The viable lactic acid bacteria (LAB) counts after 4 weeks ripening of the cheeses with 4 types of salts were $1.4 \times 10^{8}, 1.6 \times 10^{8}, 1.3 \times 10^{8}$, and $1.3 \times 10^{8} \mathrm{CFU} / \mathrm{ml}$, respectively. The water soluble nitrogen level of the cheese salted with Himalayan rock salt was the highest $(109.23 \mu \mathrm{g} / \mathrm{g})$ among those of all the cheeses at 4 weeks ripening. Organic acids in all the cheeses decreased as the ripening period advanced. Protein hydrolysis proceeded faster refined salted cheese than other salted cheeses after 4 weeks ripening. Octadecanoic acid and hexadecanoic acid (volatile fatty acid) which were detected in the cheeses with refined salt and Himalayan rock salt were lower than those with baked refined salt and sun-dried salt. In terms of textural characteristics there were substantially steep decreases in hardness, gumminess, and chewiness after 4 weeks ripening, while springiness and cohesiveness decreased less in all the Camembert cheeses. With respect to sensory properties, the taste score of the cheese with refined salt were significantly higher than those with baked refined salt, sun-dried salt and Himalayan rock salt. These results suggested that the refined salt should be recommended for Camembert cheese making.
\end{abstract}

Keywords: Camembert cheese, Salts, Physicochemical characteristic, Texture, Volatile fatty acid

\section{Introduction}

The soft and mold-ripened cheeses the most well known in the world is Camembert cheese which is aged by inoculating with Penicillium camembert and Geotrichum candidum. It is native of the Camembert region of northern France. The cheese is ripened very quickly due to high moisture content and rapid growth of the surface mold [1]. The action of mold protease, in addition to the proteolytic actions of the coagulant and the protease from the starter culture, transforms the insoluble casein into acidsoluble $\mathrm{N}$ fragments [2]. Especially, the strong activity of

\footnotetext{
*Correspondence: namsoo@cnu.ac.kr

${ }^{1}$ Department of Animal Biosystem Science, College of Agriculture and Life Sciences, Chungnam National University, Daejeon 34134, Republic of Korea

Full list of author information is available at the end of the article
}

mold protease and lipase transformed rapidly insoluble casein into water soluble peptides.

In cheese ripening terminology, cheese ripening is usually divided into interior or surface ripened cheese. Surface ripened cheese is divided into smear- and moldripened cheese. Typical examples of interior ripened cheeses are cheeses that are either submerged in brine and stored in barrels, tins or airtight cartons cheeses that are wrapped in plastic foil directly after production and stored in this way, like rindless varieties of Continental cheeses. All ripened cheeses are subject to a ripening process by which the cheese constituents are modified or degraded through the action of indigenous milk enzymes, added enzymes and enzymes of microbial origin. Over and above the general interior ripening many cheeses are subject to surface ripening. Surface ripening may again 
be divided into smear ripened cheeses and mold ripened cheeses [3]. Ripening of the surface mold-ripened cheeses, Camembert and Brie, is characterized by the very marked softening and almost liquefaction of the cheese body from surface to center. This ripening pattern is due mainly to combination of $\alpha_{\mathrm{s} 1-}$ casein hydrolysis and $\mathrm{pH}$ gradient decreasing from surface to center, due to ammonia production by the surface mold, $P$. camemberti, and its inward diffusion, catabolism of lactic acid, and outward diffusion of calcium [4-6]. Salt influences cheese ripening principally through its effect on water activity. Among the principal effects of salts are control of microbial growth and enzyme activity, syneresis of the curd and subsequent reduction of moisture of cheese curd, and physical changes in cheese proteins. The salt level of cheese ranges from $\sim 0.7 \%$ in Emmental to $\sim 6 \%$ for Domiati. The salt level of Camembert cheese is $2.5 \%$ [7]. The major feature of cheese salting is direct contribution to flavor $[8,9]$. Saltiness of cheese is highly appreciated by many peoples and regarded as one of the four basic flavors. The characteristic taste of salt, sodium chloride, is due to sodium ion [10].

Few studies have been conducted on the effect of salt types to natural cheeses, especially in Camembert cheese. Therefore, the objectives of this study were to prepare.

Camembert cheeses with refined salt, baked refined salt, sun-dried salt, and Himalayan rock salt and to compare physicochemical, textural and sensory characteristics of the Camembert cheeses during 4 weeks ripening periods.

\section{Materials and methods}

\section{Compositions of raw milk and Camembert cheese}

Raw cow milk was obtained from the milking herd of Holstein-Friesian breed at the Animal Resources Research Center, Chungnam National University located at Cheongyang, Chungnam, South Korea. Milk compositions were measured by MilkoScan ${ }^{\mathrm{TM}} \mathrm{FT}+(\mathrm{FOSS}$, Hilleroed, Denmark). The total solids content of Camembert cheeses was determined by vacuum oven sand pan method in a vacuum drying oven (VOS-201SD, Eyela, Japan) at $70{ }^{\circ} \mathrm{C}$ for $24 \mathrm{~h}$ [11]. Fat content was measured by a Rose-Gottlieb method [12]. Protein content was measured by a Kjeldahl method [13].

\section{Starter culture}

Starter cultures used were the DVS (Direct Vat Set) cultures composed of Lactococcus cremoris, Lactococcus diacetylactics, Lactococcus lactics, Leuconostoc mensenteroides (CH-N11, Chr-Hansen Co., Denmark). The Penicillium candidum (Chr-Hansen Co., Denmark) was added on the surface of the experimental Camembert cheeses.

\section{Salts}

Four types of salts used were refined salt (Hanju Ltd., Korea), baked refined salt (Hanju Ltd., Korea), sun-dried salt (Shinyi Ttd., Korea), and Himalayan rock salt (Irae Marketing Ltd., Pakistan). Salting was carried out in 21\% brine for 70 min at $4{ }^{\circ} \mathrm{C}$.

\section{Ripening of cheese}

Camembert cheeses were prepared by the Scott [14] method (Fig. 1). Initially, they were ripened for 1 week in the ripening room $\left(12{ }^{\circ} \mathrm{C}, \mathrm{RH} 95 \%\right)$, and then secondary ripening was carried out at $4{ }^{\circ} \mathrm{C}$ for $2-4$ weeks.

\section{$\mathrm{pH}$}

$\mathrm{pHs}$ of cheese samples were determined weekly using the methods [15]. A $10 \mathrm{~g}$ cheese sample and $20 \mathrm{ml}$ sterilized water were homogenized using a homogenizer (ULTRA TURRAX T25, Janke \& Kunkel, IKA-Labortechnic Germany) for $5 \mathrm{~min}$ at 20,000 rpm, and then the $\mathrm{pH}$ of a sample was measured weekly for 4 weeks using a $\mathrm{pH}$ meter (S-20 K, Mettler Toredo Co., USA) [16].

\section{Viable cell count}

Cheese samples were taken weekly, mixed with sterilized water at 1:2 ratio as was done for $\mathrm{pH}$. The number of viable cell count was determined by the method [17], using Standard plate count agar (Becton, Dickinson Co., USA) and BCP agar (Eiken Chemical Co., Ltd. Japan).

\begin{tabular}{|c|}
\hline 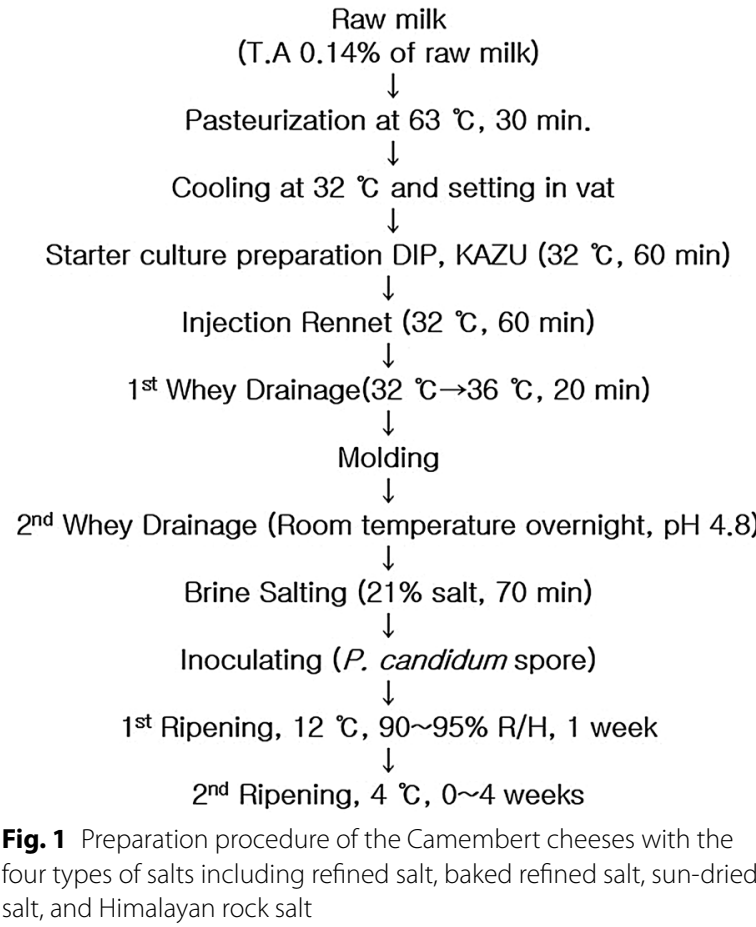 \\
\hline
\end{tabular}




\section{Water soluble nitrogen (WSN)}

Changes in WSN of cheeses were measured to estimate the extent of protein degradation during ripening period $[18,19]$. The cheese samples were homogenized with a homogenizer (ULTRA TURRAX T25, Janke \& Kunkel, IKA Labortechnic, Germany) with sterilized water and cheese at a ratio of 4: 1 (20 g cheese and $90 \mathrm{~mL}$ sterilized water) and centrifuged at $1800 \times \mathrm{g}($ Mega 17R, Hanil Science Industrial, Korea). After centrifugation for $30 \mathrm{~min}$., the supernatant was filtered through Whatman No.2, and $2.5 \mathrm{ml}$ of reagent A (12\% trichloroacetic acid) and $0.5 \mathrm{ml}$ distilled water was added to supernatant [19]. The mixture was allowed to stand at room temperature for $20 \mathrm{~min}$ and the supernatant was filtered through Whatman No. 42 (GE Healthcare Life Sciences, UK) and decanted $2.5 \mathrm{ml}$. Five $\mathrm{ml}$ of reagent B $(500 \mathrm{~mL}$ distilled water, $75 \mathrm{~g}$ sodium carbonate and $10 \mathrm{~g}$ sodium hexametaphosphate) and $1.5 \mathrm{ml}$ of reagent $C(50 \mathrm{ml}$ phenol regent and $100 \mathrm{ml}$ distilled water) were successively added to $2.5 \mathrm{ml}$ of the filtrate. After the color development, WSN content was measured at the absorbance of $570 \mathrm{~nm}$ using a UV-spectrophotometer (UV-1700, Shimadzu Co., Japan), and the concentration was calculated according to the linear equation using tyrosine as a standard [16].

\section{Protein, sugar and organic acid assays}

The mixtures of sterilized water and cheese sample at a ratio of 2:1 were homogenized, and centrifuged at $4000 \times g$ for $10 \mathrm{~min}$ using a centrifuge (Mega 17R, Hanil Science Industrial, Korea). The supernatant was collected and filtered using $0.2 \mu \mathrm{m}$ membrane filter. Protein was determined by HPLC system (600E Multisolvent Delivery System, Waters Associates, USA), and amino acid and glucose conversion were also analyzed. Twenty microliters of the samples were injected into the 7725 injector (Rheodyne, A, USA). The detector used was a 2487 UV detector (Waters Associate, USA) for protein and organic acid analyses. Sugar content was analyzed using a refractive index detector (2410 RI Detector, Waters Associates, USA). The columns used for protein analyzation and for sugar and organic acid analyzation were Vydac218TP ${ }^{\mathrm{TM}}$ C18 (Grace Division Discovery Science, USA), and Supercogel C-610H (38 cm $\times 7.8 \mathrm{~mm}$, Supelco, USA), respectively. The temperature was set at $40{ }^{\circ} \mathrm{C}$ using a Waters Column Heater Module (CHM095M, Waters Associates, USA). The mobile phase was subjected to organic acid and glucose conversion test at a flow rate of $0.5 \mathrm{ml} /$ min using $0.1 \%$ phosphoric acid and water (TEDIA Company Inc., USA). Protein analysis was performed using the mobile phase A of $0.1 \%$ TFA (Trifluoroacetic acid) and the mobile phase B of $0.1 \%$ TFA in acetonitrile at a flow rate of $1.0 \mathrm{ml} / \mathrm{min}$ for $40 \mathrm{~min}$. The standard reagents for sugars, e.g., lactose, glucose, galactose, fructose, and sucrose and for organic acids, e.g., acetic acid, oxalic acid, citric acid, lactic acid, propionic acid, butyric acid, and succinic acid used for the experiments were purchased from Sigma-Aldrich Co. in Germany [16].

\section{Fat extraction}

Five grams of cheese sample were mixed with $25 \mathrm{ml}$ ether for fat extraction, and shaken for $3 \mathrm{~h}$ at $30{ }^{\circ} \mathrm{C} / 200 \mathrm{rpm}$ [20]. The supernatant of fat extract was decanted, and concentrated using nitrogen gas to a volume of $1 / 16$.

\section{Volatile fatty acid determination}

Changes in fatty acid profiles during cheese ripening were determined using a gas chromatograph [20]. Volatile concentrates were analyzed with HP 6890 FID GC system (Agilent Tech, USA), using HP-5MS column $(30 \mathrm{~m} \times 0.25 \mathrm{~mm} \times 0.25 \mu \mathrm{m}$, Agilent Tech, USA). The sample extract was injected into the GC injector and heated to $190{ }^{\circ} \mathrm{C}$ at the rate of $6{ }^{\circ} \mathrm{C} / \mathrm{min}$ and then held at $190^{\circ} \mathrm{C}$ for $10 \mathrm{~min}$. The carrier gas was nitrogen at a rate of $35 \mathrm{ml} / \mathrm{min}$ [16].

\section{Texture analysis}

The change in physical properties of cheese samples was evaluated by texture profile analysis (TPA) using a texture analyzer (Model TA-XT2i, Stable Micro Systems, England) [21, 22]. Probe is stainless steel rod (P/5, diameter $4 \mathrm{~mm}$ ) and sample size is $20 \mathrm{~mm} \times 20 \mathrm{~mm} \times 20 \mathrm{~mm}$. The operating condition of the texture analyzer is shown in Table 1.

\section{Sensory evaluation}

The sensory evaluation panel was composed of 40 untrained panelists of students (20 to 30 years old) and faculty at Chungnam National University in Korea. The panelists evaluated sensory characteristics of Camembert

\begin{tabular}{lc}
$\begin{array}{l}\text { Table } \mathbf{1} \text { The operating condition of } \\
\text { analyzer }\end{array}$ & TA-XT2i texture \\
\hline Measurement & Condition \\
\hline Probe & $\begin{array}{c}\text { Stainless steel } \\
\text { rod (diameter } \\
4 \mathrm{~mm})\end{array}$ \\
& $5.0 \mathrm{~mm} / \mathrm{s}$ \\
Pre-test speed & $1.0 \mathrm{~mm} / \mathrm{s}$ \\
Test speed & $5.0 \mathrm{~mm} / \mathrm{s}$ \\
Post-test speed & $20.0 \mathrm{~mm} / \mathrm{s}$ \\
Distance & $5.00 \mathrm{~s}$ \\
Time & $70 \%$ \\
Strain & Grams \\
Force &
\end{tabular}


cheeses, such as hardness, flavor, bitterness and salty taste using 7 hedonic scores (7; very strong, 6; strong, 5; a little strong, 4; moderate, 3; a little weak, 2; weak, 1; very week). The taste evaluated using 7 -scores hedonic scale (7; very good, 6; good, 5; a little good, 4; moderate, 3; a little bad, 2; bad, 1; very bad). Prior to sensory evaluation, Camembert cheese ripened for 4 weeks were held for $2 \mathrm{~h}$ at room temperature and then cut into representative rectangular slices $(20 \mathrm{~g})$. The samples were served in a random order with a 7- digit code. Water and cracker were provided to clean the mouth between testing.

\section{Statistical analysis}

All experimental data were analyzed for ANOVA, least square means, and Duncan's Multiple Mean Comparison using SAS program (SAS 9.3 Institute Inco, USA). The significance level between treatment means was $\mathrm{P}<0.05$.

\section{Results and discussion General compositions}

Milk compositions are protein $3.24 \%$, fat $4.48 \%$, lactose $4.62 \%$, moisture $86.96 \%$ and total solids $13.04 \%$. And compositions of Camembert cheese at before brining were protein $17.23 \%$, fat $25.46 \%$, water $53.3 \%$ and total solids $46.70 \%$. The compositions of 4 week ripened Camembert cheese are protein $20.49 \%$, fat $28.27 \%$, water $50.50 \%$ and total solids $49.50 \%$. These results is due to the decrease in moisture as the ripening progresses for 4 weeks.

\section{Change in $\mathrm{pH}$ of cheese}

Changes in $\mathrm{pH}$ of the Camembert cheeses salted with the 4 types salts during 4 weeks ripening are shown in Fig. 2a. The initial pHs of the 0 week ripened cheeses salted with the four types of salts including refined salt, baked refined salt, sun-dried salts and Himalayan rock salt were $4.93,4.92,4.95$, and 4.97 , respectively, which decreased slightly to $4.85,4.75,4.74$, and 4.75 , respectively during 1st week ripening. The $\mathrm{pH}$ values increased slightly continuously during 2 nd and $3 \mathrm{rd}$ week ripening. The $\mathrm{pH}$ values of the cheeses with refined salt, baked refined salt, sun-dried salts and Himalayan rock salt increased dramatically to $6.83,6.94,7.12$, and 7.05 , respectively, during final 4th week ripening. The $\mathrm{pH}$ of Camembert cheese with sun-dried salt was the highest among four types of salts. The slight difference in $\mathrm{pH}$ depending on the types of salt was considered to be due to the difference in the components of refined salts and non-refined salts. These outcomes of our study on the Camembert cheeses were in agreement with the previous several reports. Schlesser et al. [2] also observed that $\mathrm{pH}$ of the Camembert cheese increased rapidly from 4.5 to 6.4 after 50 days ripening. Salt concentration had major influences on proteolysis and $\mathrm{pH}$ changes, as well as on surface mold growth. As the $\mathrm{pH}$ of the surface of the cheese increases, calcium phosphate precipitates as a layer of $\mathrm{Ca}_{3}\left(\mathrm{PO}_{4}\right)_{2}$, which results in a calcium phosphate gradient from center to surface and the migration of calcium phosphate towards the surface. Reduction in the concentration of calcium phosphate, together with increased $\mathrm{pH}$ and proteolysis, results in softening if the interior, which is characteristic of mature Camembert-type cheese [23].

\section{Change in viable cell count}

Figure $2 \mathrm{~b}$ displays the changes in viable lactic acid bacteria (LAB) of the Camembert cheeses salted with the 4 types salts during 4 weeks ripening. The general trend of the number of $L A B$ revealed that there were similar decreases in LAB in all the Camembert cheese salted with the 4 types salts. The LAB counts of the unripened cheeses with refined salt, baked refined salts, sundried salt, and Himalayan salt were $1.7 \times 10^{10}, 2.0 \times 10^{10}$, $1.7 \times 10^{10}$, and $1.0 \times 10^{10} \mathrm{CFU} / \mathrm{ml}$, respectively, which decreased dramatically to $4.7 \times 10^{8}, 6.0 \times 10^{8}, 4.2 \times 10^{8}$, and $3.6 \times 10^{8} \mathrm{CFU} / \mathrm{ml}$, respectively after 2 weeks ripening. They then decreased to $1.4 \times 10^{8}, 1.6 \times 10^{8}$, $1.3 \times 10^{8}$ and $1.3 \times 10^{8} \mathrm{CFU} / \mathrm{ml}$, respectively, after the final 4 weeks ripening. Lactose depletion by mold and $\mathrm{LAB}$ and salt addition might be accountable for the decreases of $L A B$ during ripening. These results suggested that since starter culture was affected by the 4 type salts, there was slight difference in the growth during Camembert cheese ripening.

\section{Change in water soluble nitrogen (WSN)}

Changes in water soluble nitrogen levels of the Camembert cheeses during 4 weeks ripening are shown in Fig. 2c. Proteolysis occurred during cheese ripening with concomitant effects of increased storage time and storage temperature [24, 25]. Increase of WSN in the cheeses indicates protein degradation in the cheese products. The WSN levels gradually increased, especially after 2 weeks ripening. The WSN levels in the cheese with refined salt $(104.77 \mu \mathrm{g} / \mathrm{g})$, baked refined salt $(106.92 \mu \mathrm{g} / \mathrm{g})$, sun-dried salt $(105.69 \mu \mathrm{g} / \mathrm{g})$, and Himalayan rock salt $(109.23 \mu \mathrm{g} / \mathrm{g})$ increased at the final 4 weeks ripening. These results suggested that since chymotrypsin (rennet) and starter culture were affected by 4 type salts, there was a slight difference in the hydrolysis of casein during Camembert cheese ripening. Schlesser et al. [2] reported that the amount of acid soluble nitrogen level of Camembert cheese increased to about $50 \%$ after 50 days ripening.

\section{Change in lactose and organic acid}

Lactate metabolism is perhaps of most importance in the ripeninh of surface mold-ripened cheeses (example 

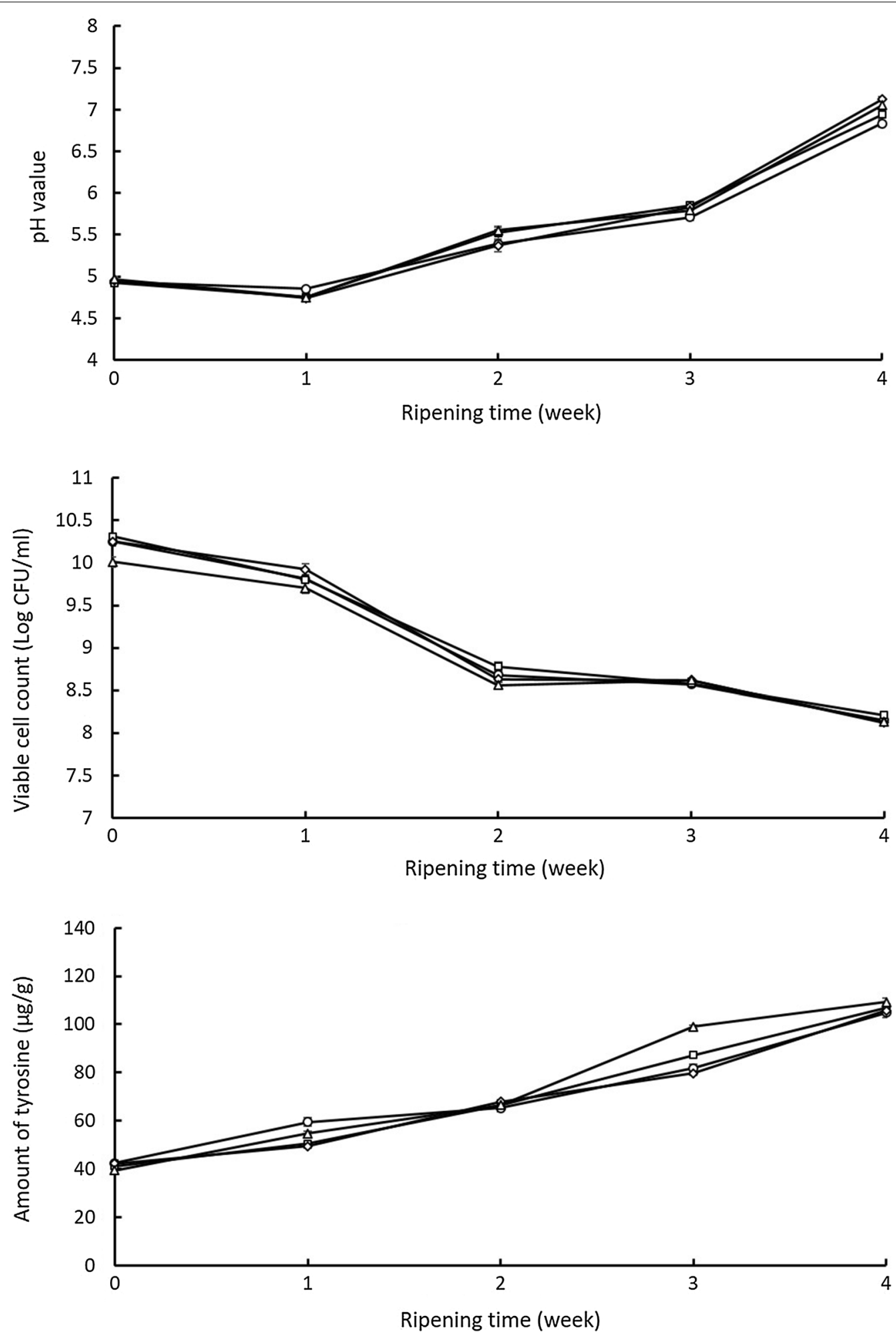

Fig. 2 Changes of pH, viable cell count, and amount of tyrosine (WSN) during 4 weeks ripening of the Camembert cheeses salted with the four types of salts. $\bigcirc-O$ : refined salt, $\square-\square$ : baked refined salt, $\diamond-\diamond$ : sun-dried salt, $\triangle-\triangle$ : Himalayan rock salt 
Camembert and Brie). Geotrichum candidum and Penicillium camembert rapidly metabolize lactate oxidatively to $\mathrm{CO}_{2}$ and $\mathrm{O}_{2}$, thus deacidifying the cheese surface [23]. Changes in carbohydrates of the Camembert cheeses salted with 4 types salts during 4 weeks ripening are shown in Fig. 3. The order of concentrations of carbohydrates of all the 0 week ripened cheeses were: lactose $>$ glucose $>$ galactose. Lactose, glucose, and galactose gradually decreased throughout 4 weeks ripening period. Lactose, glucose, and galactose might be hydrolyzed and utilized by lactic acid bacteria and mold and then disappeared mostly after 4 weeks ripening. Changes of the carbohydrates were nearly similar among all the cheeses.

Changes of organic acids in the Camembert cheeses salted with 4 types salts during 4 weeks ripening are shown in Fig. 4. Organic acid levels of the 0 week ripened cheese in the order of concentrations were: lactic acid $>$ oxalic acid $>$ citric acid $>$ propionic acid $>$ butyric acid. The organic acids rapidly decreased after 2 weeks ripening. Lactic acid remained at low level in the cheeses with sun-dried salt and Himalayan rock salt.

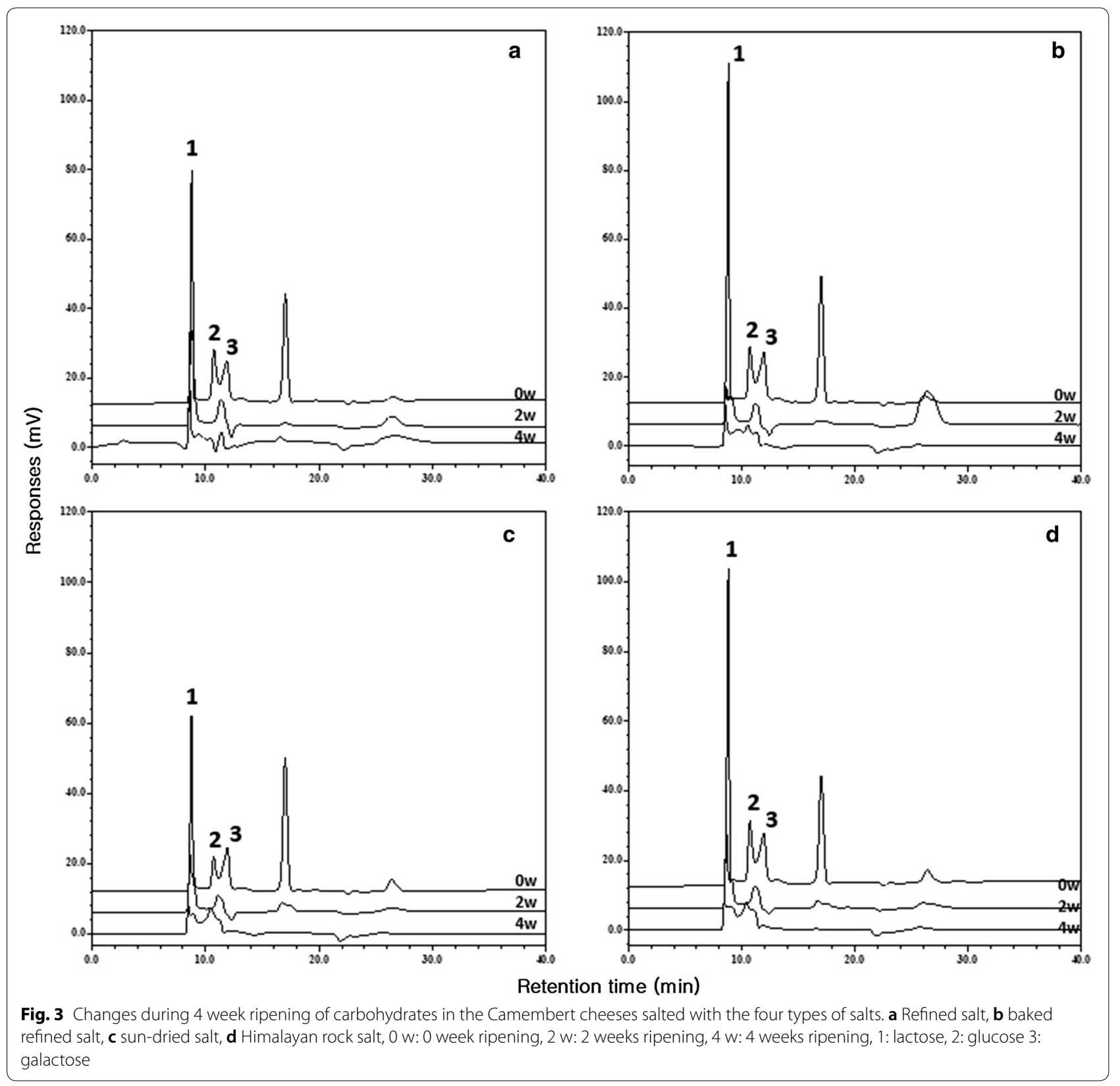




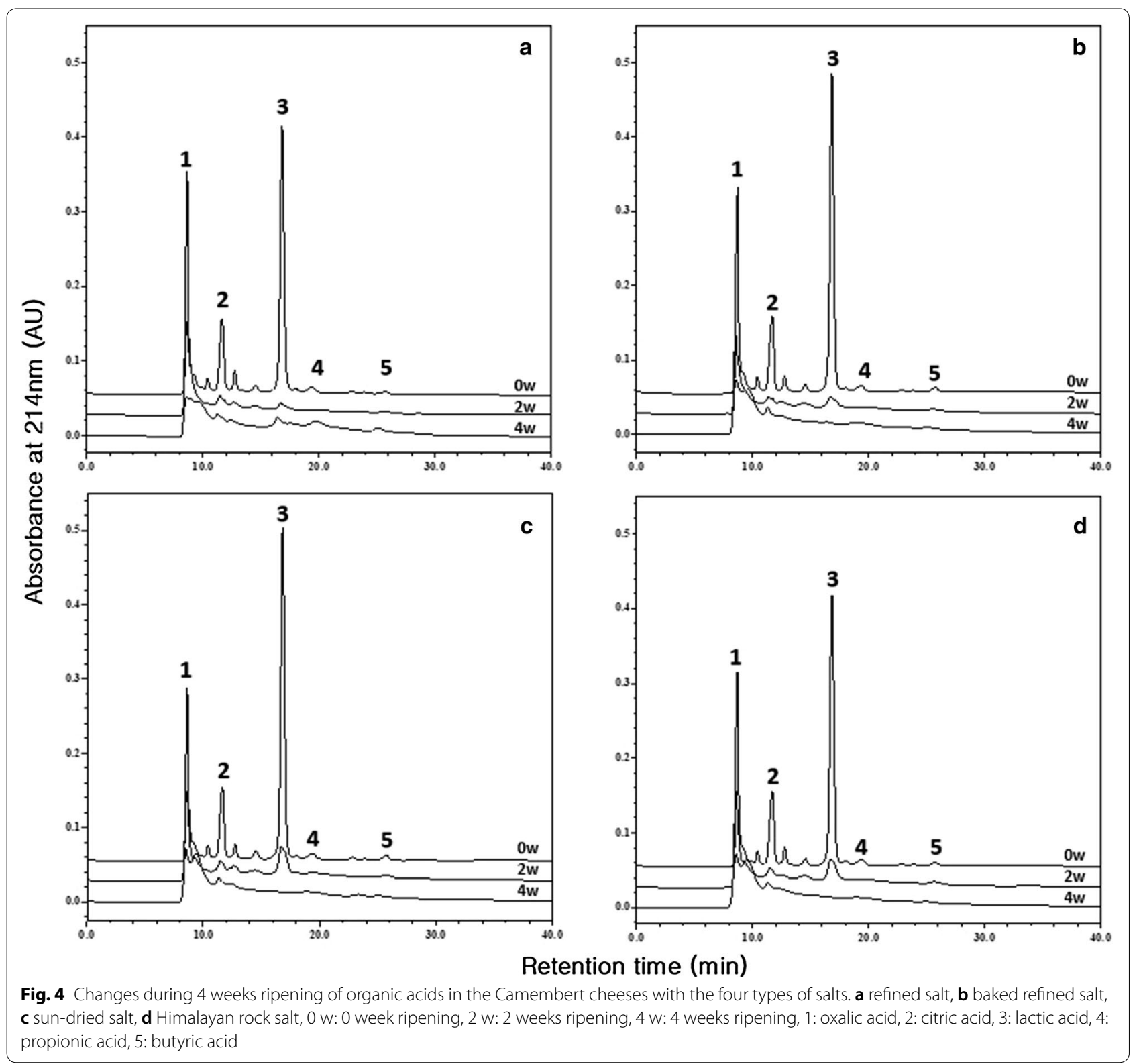

Oxalic acid remained at low level in all the cheeses, Propionic acid and butyric acid disappeared mostly during 2 weeks ripening. After 4 weeks ripening, only oxalic acid was found in significant amounts, suggesting that organic acid decreased continuously during 4 weeks ripening. Changes of organic acids during ripening also were almost similar among the cheeses. Our results are in agreement with Shin et al. [26], who observed that all organic acids continuously decreased during ripening in Emmental cheese.

\section{Change in hydrolysis of protein}

Proteolysis is the most complex and, in most varieties, the most important of the primary biochemical events that occur in most cheese during ripening. Amino acid catabolism leads to production of flavor compounds. The chymosin, the starter culture, and the mold proteases hydrolyzed the para-casein into proteose-peptone, a smaller polypeptide [2]. Hydrolysis of protein in the Camembert cheeses salted with 4 types salts during 4 weeks ripening is also displayed in Fig. 5. Casein 

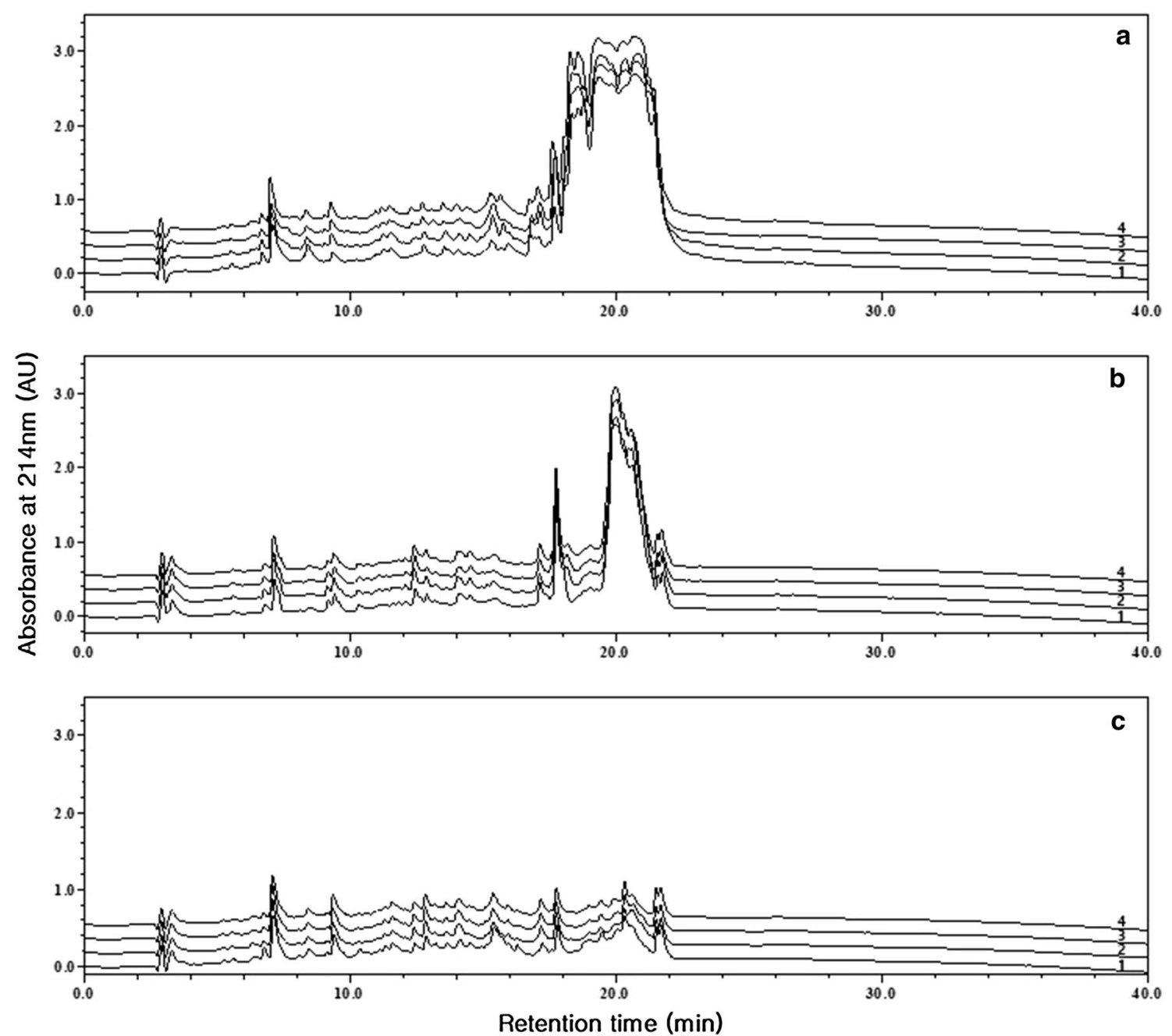

Fig. 5 Changes during 4 weeks ripening in proteolysis of the Camembert cheeses salted with the four types of salts. a 0 week ripening, 2 weeks ripening, c 4 weeks ripening, 1: refined salt, 2: baked refined salt, 3: sun-dried salt, 4: Himalayan rock salt

contents dramatically decreased in all the Camembert cheeses salted with 4 types salts during 4 weeks ripening. Degradation of both $\alpha$-casein and $\beta$-casein proceeded in sequential manner during 4 weeks ripening. As shown in Fig. 5A, the first step of ripening procedure may be hydrolysis of casein into large peptides of no bitter taste by rennet. The peptides in the cheeses separated by HPLC were observed at retention time of 17 to $22 \mathrm{~min}$. The shapes of peaks were simple, broad, and dull. As shown in Fig. 5B, small peptides were formed after ripening by lactic acid bacteria and rennet. The peptides in the cheeses after 2 weeks ripening were separated at retention time of 17 to $22 \mathrm{~min}$. The peptides were separated sharply into 2 peaks. A small peak appeared at retention time of 17.5 to $18 \mathrm{~min}$ and the other large peak occurred at retention time of 19 to $22 \mathrm{~min}$. As shown in Fig. 5c, savory peptides and amino acids by peptidases from starter and non-starter microorganisms was formed after more than 2 weeks ripening. The major 2 peaks were small sharp peaks with retention times of 17.5 and $22 \mathrm{~min}$. Elevation of protein degradation in all the cheeses salted with 4 types salts during 4 weeks ripening might be due to increase in solubility of casein at the elevated $\mathrm{pH}$ and hydrolysis of casein by plasmin and proteases produced by lactic acid bacteria and fungi. The hydrolysis pattern of proteins were similar for the 4 types of salts cheeses. However, low-molecular peptides were more produced in refined salted cheese after 4 weeks ripening. The hydrolysis of $\alpha_{\mathrm{s} 1}$-casein by milk clotting enzymes is greatly influenced by the concentration of $\mathrm{NaCl}$. The inhibitory effect of $\mathrm{NaCl}$ on proteolysis of sodium caseinate including $\alpha_{\mathrm{s} 1}$-casein and $\beta$-casein is $\mathrm{pH}$-dependent, as the extent of inhibition generally decreases at $\mathrm{pH}$ in the range 6.6-5.4 [27, 28]. 


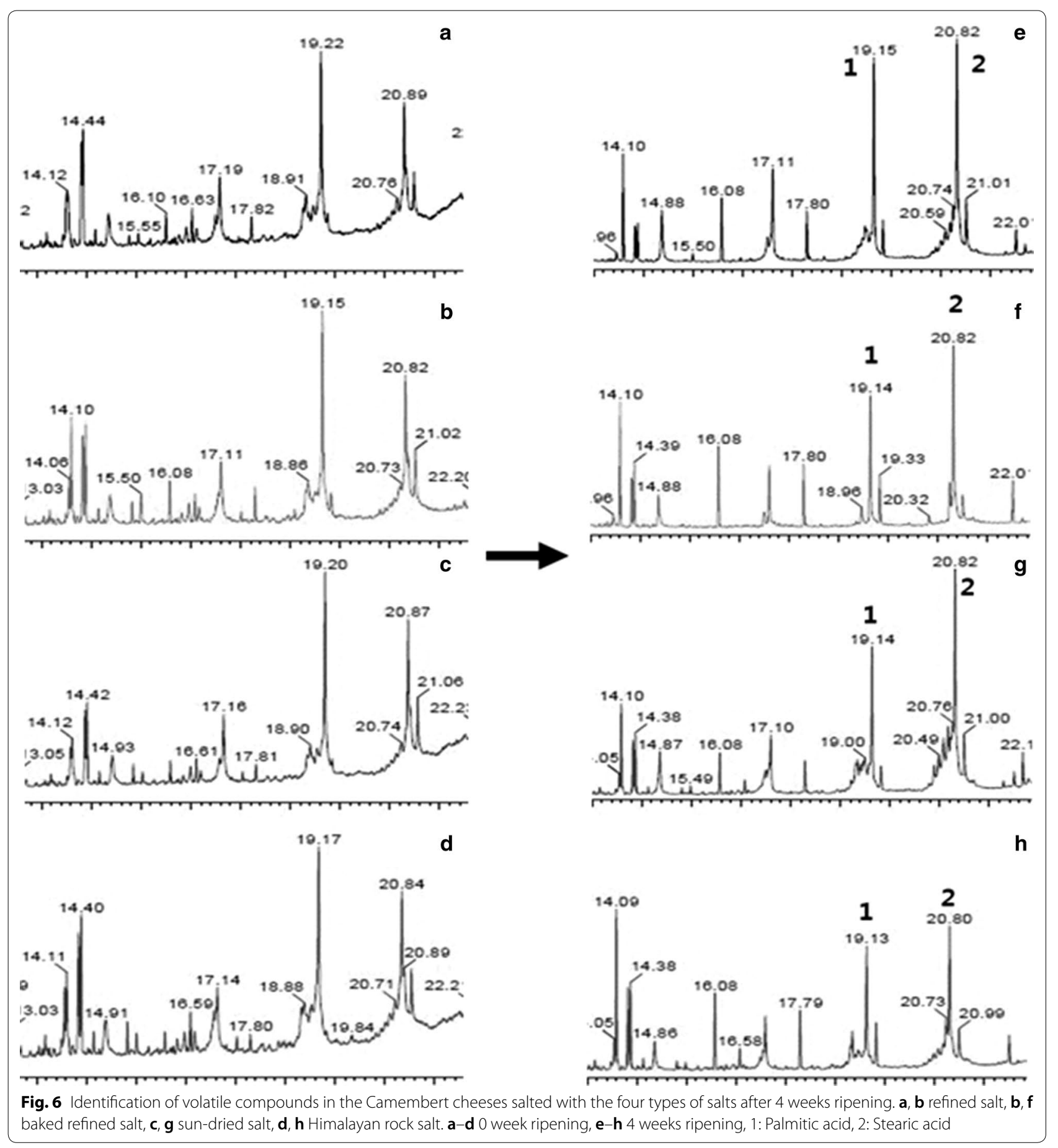

\section{Change in volatile fatty acids}

Most of the studies on the volatile components of soft cheeses have centered on mold-ripened cheeses such as Camembert, Brie, and blue cheeses. In most soft cheeses, the preliminary studies concentrated on the volatile fatty acids which are the most abundant compounds in the volatile fraction. The short chain fatty acids are the most important quantitatively in Camembert cheese [29]. The most lipolytic organisms associated with cheese are Penicillium spp., which grow on or in mold-ripened varieties 
Table 2 Flavor notes of several fatty acids found in Camembert cheese

\begin{tabular}{llll}
\hline Peak no. & Compounds & $\begin{array}{l}\text { Retention } \\
\text { time (min) }\end{array}$ & Flavor note \\
\hline 1 & Dodecanoic acid & 14.39 & Fatty, rancid \\
2 & Tetradecanoic acid & 17.11 & Unknown \\
3 & Hexadecanoic acid & 19.15 & Waxy, pungent, blue cheese \\
4 & Octadecanoic acid & 21.02 & $\begin{array}{c}\text { Unpleasant, oily, goaty, } \\
\text { soapy, waxy, musty, ran- } \\
\text { cid, fruity, sour, sweaty }\end{array}$ \\
\hline
\end{tabular}

Molimard and Spinnler [33]
[30]. Penicillium camemberti produces an extracellular lipase that is optimally active on tributyrin at $\mathrm{pH} 9$ and $35{ }^{\circ} \mathrm{C}[31]$.

Changes in volatile fatty acids in the Camembert cheeses salted with the four types of salts during 4 weeks ripening are shown in Fig. 6 and Table 2. Compositions of fatty acids of the 0 week ripened cheeses showed similar patterns in volatile fatty acid concentrations in descending order, as palmitic acid $>$ stearic acid $>$ myristic acid >lauric acid. However, the opposite pattern was shown after 4 weeks ripening in the cheeses as stearic acid $>$ palmitic acid $>$ myristic acid $>$ lauric acid. The levels

Table 3 Change of texture characteristics during ripening of the Camembert cheeses salted with the four types of salts ${ }^{a}$

\begin{tabular}{|c|c|c|c|c|c|c|}
\hline $\begin{array}{l}\text { Age of cheese } \\
\text { (week) }\end{array}$ & Four types of salts & Hardness (g) & Springiness & Cohesiveness & Gumminess (g) & Chewiness (g) \\
\hline \multirow[t]{4}{*}{0} & Refined & $1490.15 \pm 15.94^{b}$ & $1.01 \pm 0.01^{\mathrm{a}}$ & $0.62 \pm 0.01^{a}$ & $914.70 \pm 38.35^{b}$ & $955.64 \pm 15.56^{b}$ \\
\hline & Baked refined & $1407.74 \pm 68.67^{b}$ & $0.99 \pm 0.01^{b}$ & $0.53 \pm 0.06^{b}$ & $596.04 \pm 49.10^{c}$ & $594.73 \pm 48.86^{c}$ \\
\hline & Sun-dried & $2387.42 \pm 163.69^{\mathrm{a}}$ & $0.10 \pm 0.01^{b}$ & $0.65 \pm 0.04^{\mathrm{a}}$ & $1468.67 \pm 262.35^{b}$ & $1462.28 \pm 269.36^{\mathrm{a}}$ \\
\hline & Himalayan rock & $2160.10 \pm 95.56^{\mathrm{a}}$ & $1.00 \pm 0.00^{\mathrm{ab}}$ & $0.64 \pm 0.01^{\mathrm{a}}$ & $1386.61 \pm 68.11^{\mathrm{b}}$ & $1384.90 \pm 68.31^{\mathrm{a}}$ \\
\hline \multirow[t]{4}{*}{1} & Refined & $1470.15 \pm 15.94^{\mathrm{a}}$ & $1.00 \pm 0.00^{\mathrm{a}}$ & $0.61 \pm 0.02^{\mathrm{NS}}$ & $914.70 \pm 38.35^{\mathrm{a}}$ & $915.64 \pm 39.21^{\mathrm{a}}$ \\
\hline & Baked refined & $1246.11 \pm 67.02^{c}$ & $1.00 \pm 0.00^{\mathrm{a}}$ & $0.64 \pm 0.02$ & $794.24 \pm 15.69^{b}$ & $732.19 \pm 16.37^{b}$ \\
\hline & Sun-dried & $1317.04 \pm 114.84^{b c}$ & $0.97 \pm 0.00^{c}$ & $0.67 \pm 0.01$ & $887.08 \pm 76.51^{\mathrm{a}}$ & $862.08 \pm 75.90^{\mathrm{a}}$ \\
\hline & Himalayan rock & $1460.90 \pm 171.46^{\mathrm{ab}}$ & $1.00 \pm 0.02^{b}$ & $0.62 \pm 0.07$ & $893.37 \pm 4.98^{\mathrm{a}}$ & $884.65 \pm 20.79^{a}$ \\
\hline \multirow[t]{4}{*}{2} & Refined & $61.56 \pm 4.85^{\mathrm{a}}$ & $0.99 \pm 0.02^{\mathrm{a}}$ & $0.54 \pm 0.03^{\mathrm{a}}$ & $33.05 \pm 0.71^{\mathrm{a}}$ & $32.75 \pm 0.19^{\mathrm{a}}$ \\
\hline & Baked refined & $46.89 \pm 6.21^{b}$ & $0.97 \pm 0.02^{b}$ & $0.43 \pm 0.05^{b}$ & $20.32 \pm 3.32^{b}$ & $21.03 \pm 1.69^{b}$ \\
\hline & Sun-dried & $60.74 \pm 5.11^{\mathrm{a}}$ & $1.00 \pm 0.01^{\mathrm{a}}$ & $0.49 \pm 0.10^{\mathrm{ab}}$ & $29.54 \pm 4.08^{\mathrm{a}}$ & $29.44 \pm 3.94^{\mathrm{a}}$ \\
\hline & Himalayan rock & $56.82 \pm 14.20^{\mathrm{ab}}$ & $1.00 \pm 0.00^{\mathrm{a}}$ & $0.48 \pm 0.03^{\mathrm{ab}}$ & $27.67 \pm 8.16^{\mathrm{a}}$ & $27.63 \pm 8.17^{\mathrm{a}}$ \\
\hline \multirow[t]{4}{*}{3} & Refined & $59.54 \pm 0.00^{\mathrm{NS}}$ & $1.01 \pm 0.00^{\mathrm{a}}$ & $0.37 \pm 0.00^{b}$ & $21.70 \pm 0.00^{\mathrm{NS}}$ & $21.87 \pm 0.00^{\mathrm{NS}}$ \\
\hline & Baked refined & $48.30 \pm 11.17$ & $0.99 \pm 0.01^{b}$ & $0.48 \pm 0.12^{\mathrm{a}}$ & $22.65 \pm 4.91$ & $22.50 \pm 4.92$ \\
\hline & Sun-dried & $58.14 \pm 14.39$ & $0.98 \pm 0.0^{c}$ & $0.53 \pm 0.02^{\mathrm{a}}$ & $30.65 \pm 6.43$ & $30.11 \pm 6.20$ \\
\hline & Himalayan rock & $56.32 \pm 11.04$ & $1.00 \pm 0.00^{b}$ & $0.37 \pm 0.08^{b}$ & $20.70 \pm 8.97$ & $20.62 \pm 9.01$ \\
\hline \multirow[t]{4}{*}{4} & Refined & $57.21 \pm 1.27^{\mathrm{a}}$ & $0.98 \pm 0.02^{\mathrm{NS}}$ & $0.39 \pm 0.01^{b}$ & $22.09 \pm 0.83^{b}$ & $21.70 \pm 0.33^{b}$ \\
\hline & Baked refined & $54.73 \pm 7.26^{\mathrm{ab}}$ & $0.98 \pm 0.02$ & $0.52 \pm 0.04^{\mathrm{a}}$ & $28.57 \pm 5.10^{\mathrm{a}}$ & $28.09 \pm 4.80^{\mathrm{a}}$ \\
\hline & Sun-dried & $48.50 \pm 3.78^{b}$ & $0.95 \pm 0.03$ & $0.44 \pm 0.07^{b}$ & $21.06 \pm 1.84^{b}$ & $20.05 \pm 2.11^{b}$ \\
\hline & Himalayan rock & $57.75 \pm 5.54^{\mathrm{a}}$ & $0.95 \pm 0.05$ & $0.43 \pm 0.07^{b}$ & $24.95 \pm 5.35^{\mathrm{ab}}$ & $24.01 \pm 6.09^{\mathrm{ab}}$ \\
\hline
\end{tabular}

NS not significant different

${ }^{a}$ Data are expressed as mean value \pm SD of five replicates; different superscript letters within a column refer to statistically significant differences (Duncan test, $\mathrm{p}<0.05)$

Table 4 Sensory characteristics of the Camembert cheeses ripened for 4 weeks with the four types of salts

\begin{tabular}{lllll}
\hline Sensory characteristics & \multicolumn{2}{l}{ Four types of salts } & & Himalayan rock \\
\cline { 2 - 5 } & Refined & Baked refined & Sun-dried & $4.71 \pm 1.07$ \\
\hline Hardness & $4.29 \pm 0.99^{\mathrm{NS}}$ & $4.21 \pm 1.12$ & $4.71 \pm 1.07$ & $3.21 \pm 1.53$ \\
Flavor & $3.64 \pm 0.84^{\mathrm{NS}}$ & $4.36 \pm 1.34$ & $3.64 \pm 1.28$ & $3.71 \pm 1.68^{\mathrm{a}}$ \\
Bitterness & $2.42 \pm 1.22^{\mathrm{b}}$ & $4.00 \pm 1.88^{\mathrm{a}}$ & $3.36 \pm 1.34^{\mathrm{b}}$ & $3.86 \pm 1.56^{\mathrm{ab}}$ \\
Salty & $3.21 \pm 1.05^{\mathrm{b}}$ & $4.14 \pm 1.66^{\mathrm{a}}$ & $4.07 \pm 1.33^{\mathrm{ab}}$ & $3.71 \pm 1.27^{\mathrm{b}}$ \\
Taste & $5.00 \pm 1.11^{\mathrm{a}}$ & $4.14 \pm 1.66^{\mathrm{ab}}$ & & \\
\hline
\end{tabular}

NS not significant different

${ }^{a}$ Data are expressed as mean value $\pm S D$ of five replicates; different superscript letters within a row refer to statistically significant differences (Duncan test, $p<0.05$ ) 
of stearic acid and palmitic acid in descending order were refined salt cheese $>$ sun-dried salt cheese $>$ baked refined salt cheese $>$ Himalayan rock salt cheese.

It was suggested that unpleasant flavor (goaty, soapy, waxy, musty, rancid, sour) may have been converted to a milder flavor due to sun-dried salt, baked salt and Himalayan rock salt. These results were same as the data reported by Molimard and Spinnler [32], and Sablé and Cottenceau [29]. Volatile fatty acid concentrations of the Camembert cheeses in descending order was stearic acid $>$ palmitic acid $>$ myristic acid $>$ lauric acid. Lipolysis is particularly important in soft cheeses such as Camembert, where free fatty acids can be generated up to $10 \%$ of the total fatty acids present [33].

\section{Change in texture}

Textural properties of the Camembert cheeses salted with the four types of salts were compared during 4 weeks ripening period (Table 3). With respect to hardness of the Camembert cheeses, most significant decreases occurred during between 1 week ripening and 2 weeks ripening. Hardness of the 0 week ripening cheeses and the cheese after 1 week ripening was substantially higher than those after 2-4 weeks ripening. Hardness of the cheeses with refined salt at $0,1,2,3$, and 4 weeks ripening were $1490.15 \pm 15.94,1470.15 \pm 15.94,61.56 \pm 4.85$, $59.54 \pm 0.00$, and $57.21 \pm 1.27$, respectively. Hardness of the cheeses with sun-dried salt at $0,1,2,3$, and 4 weeks ripening were $2387.42 \pm 163.69, \quad 1317.04 \pm 114.84$, $60.74 \pm 5.11,58.14 \pm 14.39$, and $48.50 \pm 3.78$, respectively. Especially, hardness of the cheese baked refined salt was the lowest (1407.74 \pm 68.67$)$ and sun-dried salt was highest $(2387.42 \pm 163.69)$ at 0 week ripening.

These radical changes in hardness values appeared to be caused by the possible decomposition of cheese proteins (caseins) which might have strong proteolytic enzymes secreted by the fungus at the beginning of the 2 weeks ripening period. It is suggest that kinds of salts may have been influence on enzyme activity in Camembert cheese. Similar results have been reported by several previous $[20,24,25,34,35]$ who showed that hardness decreased with ripening of cheeses. The textural property trends of gumminess and chewiness are similar to those of hardness, where the values of gumminess and chewiness up to one week ripening were substantially higher than those of 2 to 4 weeks ripening periods in 4 kinds of salted Camembert cheese (Table 3). Also, gumminess and chewiness of baked refined salted Camembert cheese were the lowest among the 4 kinds of salted Camembert cheese at 0 week ripening. For the 4 weeks of ripening period, the baked refined salt Camembert cheese showed higher gumminess and chewiness values than other salts Camembert cheese. Although there were some variations between 4 kinds of salts Camembert cheeses in different ripening periods, springiness did not show significant differences among ripening periods ( 0 to 4 weeks), cohesiveness shown differences between 0-1 weeks and 2-4 weeks ripening periods (Table 3 ).

\section{Sensory evaluation}

Sensory scores of the Camembert cheeses salted with 4 types of salts are shown in Table 4 . Hardness of the cheeses with sun-dried salt and Himalayan rock salt, which are non-refined salt cheese was equal to $4.71 \pm 1.07$. Hardness of the cheeses with refined salt and baked refined salt were $4.29 \pm 0.99$ and $4.21 \pm 1.12$, respectively, which was lower than of non-refined salt cheese. Meanwhile, the flavor, bitterness, and salty score of the cheese with refined salt were the lowest of all the cheeses. Their taste scores were in descending order, refined salt $(5.00 \pm 1.11)>$ baked refined $(4.14 \pm 1.66)>$ sun-dried salt $(4.07 \pm 1.33)>$ Himalayan rock salt $(3.71 \pm 1.27)$. The taste score of the cheeses with refined salt was the highest of all the cheeses. These results were considered to be due to the difference in composition between refined salt and non-refined salt. The refined salt and baked refined salt have higher purity, whereas sun-dried salt and Himalayan rock salt contain impurities such as magnesium, potassium and calcium.

The Camembert cheeses salted with the four types of salts displayed a little different patterns in $\mathrm{pH}$, viable cell counts, WSN, carbohydrates hydrolysis, organic acids, texture, proteolysis, volatile compounds, and sensory properties after ripening for 4 weeks. The taste score of Camembert cheese with refined salt was significantly higher than those with other three types of salts. In conclusion, refined salt without impurities should be recommended for Camembert cheese manufacturing.

\section{Acknowledgements \\ This study was supported by research funds by Institute of Agricultural Sci- ence, College of Agriculture \& Life sciences, Chungnam National University in 2017 (1870-College of Agriculture \& Life sciences, Chungnam National University in 2017 (1870-01).}

\section{Authors' contributions}

Conceived and designed the experiments: HCB, JHN, MSN. Performed the experiments: HCB, JHN, GR. Analyzed the data: JHN, GR. Wrote the paper: HCB, $J H N, M S N$. All authors read and approved the final manuscript.

\section{Availability of data and materials}

The datasets used and analyzed in this study are available from the corresponding author on reasonable request.

\section{Competing interests}

The authors declare that they have no competing interests.

\section{Author details}

${ }^{1}$ Department of Animal Biosystem Science, College of Agriculture and Life Sciences, Chungnam National University, Daejeon 34134, Republic of Korea. ${ }^{2}$ Department of Animal Biotechnology, Sangi University, Wonju 26339, Republic of Korea. 
Received: 12 June 2020 Accepted: 7 September 2020

Published online: 06 October 2020

\section{References}

1. Mocqot G (1955) Soft cheese manufacture. J Soc Dairy Tech 1955:8-17

2. Schlesser JE, Schmidt SJ, Speckman R (1992) Characterization of chemical and physical changes in Camembert cheese during ripening. J Dairy Sci 75(7):1753-1760

3. Chr. Hansen. (2002) Cheese ripening theory. First edition. Web:chrhansen.com. 3251133.doc/Jun 1:17

4. Karahadian C, Lindsay RC (1987) Integrated roles of lactate, ammonia, and calcium in texture development of mould surface-ripened cheese. J Dairy Sci 70(5):909-918

5. Le Graet Y, Lepienne A, Brule G, Ducruet P (1983) Migration du calcium et des phosphates inorganiques dans les fromages à pâte molle de type Camembert au cours de 1'affinage. Le Lait 63(3):317-332

6. Noomen A (1983) The role of the surface flora in the softing of cheeses with a low initial pH. Neth Milk Dairy J 37(4):229-232

7. Guinee TP, Fox PF (2017) Cheese: chemistry. Physics and microbiology. In: McSweeney PLH, Fox PF, Cotter PD, Everett DW (eds) Salt in cheese: physical, chemical and biological aspects. Academic Press, New York, pp 317-375

8. Kilcast $D$, den Ridder C (2007) Sensory issues in reducing salt in food products. In: Kilcast D, Angus F (eds) Reducing salt in foods-practical strategies. Woodhead Publishing Limited, Cambridge, pp 201-220

9. Skeie S, Ardö Y, Everett DW. Salt in cheese flavor. In: The importance of $\mathrm{NaCl}$ in cheese manufacture and ripening of cheese. Special issue of the international dairy federation SI-1401, IDF Brussels, 2014. p. 42-45

10. McCaughey S (2007) Dietary salt and flavor: mechanisms of taste perception and physiological controls. In: Kilcast D, Angus F (eds) Reducing salt in foods practical strategies. Woodhead Publishing Limited, Cambridge, pp 77-98

11. Nielsen SS. Determination of moisture content. B. Vacuum oven, Food analysis laboratory manual. New York: Springer, p. 21

12. AgriMoon Team (2015) http://www.agrimoon.com/determinat ion-of-fat-in-milk

13. Ilirjana B, Gentiana B. (2013) Determination of protein content in milk by Kjeldahl method interlaboratory study. https://www.researchgate.net/ publication/274023099

14. Scott R (1998) Cheese making practice, 3rd edn. Springer, New York, pp 345-349

15. Choi HY (2011) Application in Gouda-type cheese manufacture added with Korea traditional wines. Ph. D. thesis, Sunchon National Univ., Sunchon, Korea

16. Nam MS, Nam JH, Bae HC, Renchinkhand G, Park YW (2019) Physicochemical properties of rice powder added Camembert cheese during 4 weeks ripening. 7(3): 229

17. Marshall RT (1993) Standard methods for the examination of dairy product, 16th edn. American Public Health Association, Washington, pp 299-308

18. Bütikofer U, Rüegg M, Ardö Y (1993) Determination of nitrogen fractions in cheese: evaluation of a collaborative study. LWT-Food Sci Technol 26(3):271-275

19. Hull ME (1947) Studies on milk proteins. II. Colorimetric determination of the partial hydrolysis of the proteins in milk. J Dairy Sci 30(11):881-884
20. Han YS (1995) Comparison of GC profile and sensory properties of fermented cheese flavor concentrates and cheese varieties. J Kor Soc Food Sci Nutr 24(6):925-931

21. Sousa MJ, McSweeney PLH (2001) Studies on the ripening of Cooleeney, an Irish farmhouse camembert-type cheese. Irish J Agric Food Res 40(1):83-95

22. Wang J, Li L (2012) Comparative study of chemical composition and texture profile analysis between Camembert cheese and Chinese sufu. Biotech Frontier. 1(1):1-8

23. McSweeney PLH, Fox PF, Ciocia F. Metabolism of residual lactose and of lactate and citrate. In: McSweeney PLH, Fox PF, Cotter PD, Everett DW. Editors. Cheese: chemistry, physics and microbiology, vol 1: general aspects, 4rd ed, London: Elsevier; p. 411-421

24. Park YW (2001) Proteolysis and lipolysis of goat milk cheese. J Dairy Sci 84:E84-E92

25. Jin YK, Park YW (1995) Effect of aging time and temperature on proteolysis of commercial goat milk cheeses produced in the US. J Dairy Sci 78(12):2598-2608

26. Shin YK, Oh NS, Nam MS (2011) Changes of organic acids and free fatty acids during the ripening of Emmental cheese. Kor J Food Sci Anim 31(6):928-934

27. Mulvihill DM, Fox PF (1980) Proteolysis of $\mathrm{a}_{51}$-casein by chymosin in dilute $\mathrm{NaCl}$ solutions and in Chaddar cheese. Irish J Food Sci Technol 4(1):13-23

28. Lane CN, Fox PF (1999) The individual or combined action of chymosin and plasmin on sodium caseinate or $\beta$-casein in solution: effect of $\mathrm{NaCl}$ and $\mathrm{pH}$. Le Lait 79(4):423-434

29. Sablé S, Cottenceau G (1999) Current knowledge of soft cheeses flavor and related compounds. J Agric Food Chem 47(12):4825-4836

30. McSweeney PLH (2004) Biochemistry of cheese ripening. Inter J Dairy Technol 57(2):127-144

31. Lamberet $G$, Lenoir J (1976) Les caractères du systèm lipolytique de 1'espèce Penicillium caseicolum. Nat du système. Le Lait 56(2):119-134

32. Molimard P, Spinnler HE (1996) Review: compounds involved in the flavor surface mold-ripened cheese: origins and properties. J Dairy Sci 79(2):169-184

33. Abbas A, Dobson ADW. Penicillium camembert: Penicillium camembert and cheese flavor. Roginski H, Fuquay JW, Fox PF. editors. Encyclopedia of dairy science. 2nd ed. New York: Academic Press; 2011. p. 776-779

34. Lee JW, Lee SW, Jeong JH, Yang R (1990) Change in caseins during the ripening of Camembert cheese. Kor J Food Sci Tech 22(3):337-342

35. Bea HY (2007) The Study of cholesterol-reduced camembert cheese on physicochemical and sensory attributes during ripening and storage. Master's thesis, Sejong Univ., Seoul, Korea

\section{Publisher's Note}

Springer Nature remains neutral with regard to jurisdictional claims in published maps and institutional affiliations.

\section{Submit your manuscript to a SpringerOpen ${ }^{\circ}$ journal and benefit from:}

- Convenient online submission

- Rigorous peer review

- Open access: articles freely available online

- High visibility within the field

- Retaining the copyright to your article

Submit your next manuscript at springeropen.com 